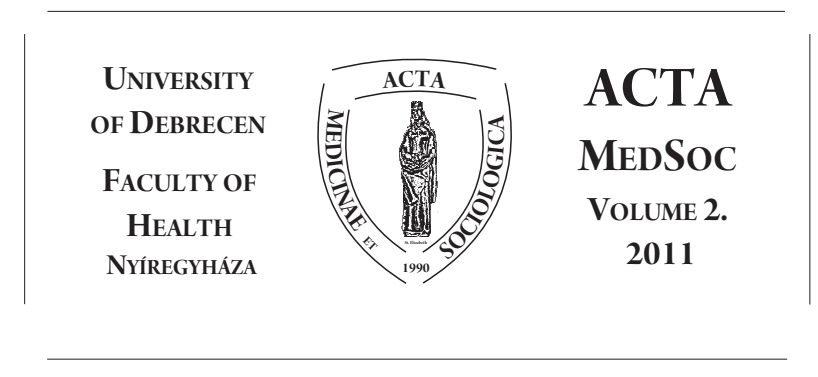

\title{
Az önkormányzatok szerepének változása a szociális szektorban
}

\author{
Krizsai Anita
}

Nyíregyháza Megyei Jogú Város Polgármesteri Hivatal, Szociális Osztály

\begin{abstract}
Change the role of local governments in the social sector.
This study is about, how to share responsibilities between the state and local autirities to provide social services, and to take part in the public governance. The topic is popular, because the centralisation of our time is quietly becoming fashionable in Hungary. The research was made at the end of 2009. It observes the current situation round the central bodies, how the examination and the licensing of personal social services are done. I am conviced that the present system of social provision needs transformation, because local governments should have less functions, but it has to keep the basic roles of need assessment, planning and coordination.
\end{abstract}

Lektor: Dr. Sipos László, fóiskolai docens, DE-EK

DOI: $10.19055 / \mathrm{ams} .2011 .2 / 2 / 7$

\section{Jogszabályi háttér}

A rendszerváltás előtti Magyarországon az állam a közjavak részeként a szociális szolgáltatásokat saját hatáskörében biztosította. A rendszerváltást követôen alapvetô változásokra került sor. Az önkormányzatok létrejöttével és a civil szektor megjelenésével az állam szerepe is megváltozott. Az új helyzetben a szociális szolgáltatások és ellátások biztosításának kötelezettsége helyi önkormányzati hatáskörbe került, az állam szerepe a jogszabályi keretek meghatározására és a finanszírozásra korlátozódott. Ugyanakkor már ekkor megfogalmazódott az igény arra, 
hogy az állam azonos módon biztosítsa a feladatok ellátásában történő közremúködés lehetôségét (szektorsemlegesség). Mindez bonyolultabb szabályozást igényelt. A közigazgatásban tehát a hagyományos államigazgatási és hatósági feladatok mellett megjelentek a szervezési és szolgáltatatási feladatok is. A települési önkormányzatok, mint a közszektor szereplői, a jelenlegi szabályozó rendszer alapján kettős szerepkörben vannak. Egyrészt kötelezô feladatuk a közszolgáltatások szervezése (oktatási, egészségügyi, szociális feladatok), másrészt számos hatósági igazgatási feladatot látnak el, mint a közigazgatás általános hatáskörú szervei (a hatáskörök jegyzőre történő telepítése révén). A jelenlegi joggyakorlat szerint az intézmények és a szolgáltatók csak múködési engedély birtokában kezdhetnek szolgáltatást nyújtani, de az engedély az állami normatívához való hozzájutásnak a feltétele is. Az elmúlt években kísérletek történtek arra, hogy a normatív finanszírozás helyett a szolgáltatások terén kialakuló területi egyenlőtlenségek kiegyenlítését célzó finanszírozás (támogató szolgálat, közösségi ellátás, jelzőrendszeres házi segítségnyújtás, foglalkoztatási engedély) valósuljon meg, mely a szektorsemlegességet és az egyenlő hozzáférést is biztosítani kívánta.

A szociális szolgáltatások szervezésének szabályait a szociális igazgatásról és szociális ellátásokról szóló 1993. évi III. törvény (továbbiakban: Szt.) határozza meg, mely szerint a település nagyságától függően változik a kötelezóen ellátandó feladatok köre, végrehajtási rendelete (a szociális szolgáltatók és intézmények múködésének engedélyezésérôl és ellenőrzésérôl szóló 321/2009. (XII. 29.) Korm. rendelet) pedig a múködési engedélyezés hatósági feladatait tartalmazza.

Az elmúlt idôszakban számos tanulmány jelent meg a szociális szolgáltató rendszer átalakításának szükségességérôl (egyre inkább szükségessé válik a piaci viszonyokra jellemzô követelmények megvalósításának biztosítása: az állampolgár számára választhatóság, egyenlő hozzáférés biztosítása, szektorsemlegesség), mellyel kapcsolatosan felmerül a kérdés, az állam szerepe meddig terjedhet, illetve az önkormányzatok feladata hogyan változhat.

A szociális szolgáltatók és intézmények múködésének engedélyezésérôl és ellenőrzéséról szóló 321/2009. (XII. 29.) Korm. rendelet (Szmr.) 2011. július 1-jével hatályba lépô módosítása alapján a megyei, fôvárosi kormányhivatalok szociális és gyámhivatalainak hatáskörébe kerül valamennyi szociális szolgáltatás múködési engedélyezésével és ellenőrzésével kapcsolatos feladat. A hatáskörváltozással az önkormányzatoknak megszünik az igazgatási feladata a múködési engedélyek és ellenőrzések terén. A jogszabály módosítással összefüggésben megjelent tájékoztató szerint a szociális és gyámhivatalok keretében biztosított lesz ezen feladatok magas színvonalon, kellô szakértelemmel, megfelelő gyakorlati ismeretekkel és egységes szakmai elvek mentén történô ellátása.

\section{A kutatás háttere}

2008. év végén „Központi szociális információs fejlesztés” kiemelt program indult (TÁMOP 5.4.2.) Európai Uniós támogatással, a Foglalkoztatási és Szociális Hivatal 
fejlesztésében és koordinációjában. 2009 novembertól 2010. január végéig került sor a kérdőíves felmérésre. ${ }^{1}$ A kérdőívben a 2009 évben folytatott gyakorlatra kérdeztünk rá, a kérdések érintették a jogszabályi változásokat, a közigazgatási hatósági eljárás és szolgáltatás általános szabályairól szóló 2004. évi CXL. törvény (továbbiakban: Ket.) 2009. október 1. napjától hatályos módosulását, illetve az ágazati jogszabályok terén bekövetkezett változásokat is.

A négy részből álló kérdőív fő témakörei a következók voltak:

- a hivatalok rendelkezésére álló eróforrások (humán erőforrás, technikai feltételek, valamint az ügyfelek rendelkezésére álló eróforrásokkal kapcsolatos tapasztalatok),

- hivatali eljárások, ügymenetek megismerése,

- az ágazati szabályozók alkalmazásának gyakorlata,

- az ágazati szabályozók alkalmazhatóságának gyakorlata,

- az ágazati szabályozás változtatására tett javaslatok,

- az elektronikus ügyintézésre való áttéréssel kapcsolatos vélemények, javaslatok, észrevételek.

2011. június 30-ig engedélyezô hatóság a gyermekvédelmi és gyámügyi feladat - és hatáskörök ellátásáról, valamint a gyámhatóság szervezetérôl és illetékességérôl szóló 331/2006. (XII. 23.) Korm. Rendelet mellékletében kijelölt települési, fôvárosi kerületi önkormányzat jegyzője (számuk: 281), a szociális és gyámhivatal (számuk: 19) és a Foglalkoztatási és Szociális Hivatal (továbbiakban: FSZH).

A felmérés nem reprezentatív mintavételen alapult, mivel a válaszadásra a legtöbb engedélyt kiadó hatóságokat kértük fel (az összes engedélyezô hatóság 30\%-a ), így a feldolgozás során kapott eredményeket is ennek tükrében kell kezelni. 100 db kérdőívet küldtünk elektronikus formában a választ is így kérve, melyből 85 kérdôív érkezett vissza. Az értékelésnél azt is figyelembe kell venni, hogy az anonimitás nem volt biztosítható, a visszaérkezett válaszokból azonosítható, hogy mely hatóság küldte meg azt, ezért nem várható el, hogy minden esetben (pl.: eljárási határidők betartása) ôszinte a válasz.

A tanulmányban azokat az eredményeket szeretném bemutatni, melyek a hatáskörváltozással érintett hivatalok rendelkezésére álló eróforrásait, valamint a hivatalok változtatásra tett javaslatait és észrevételeit ismertetik.

A kutatás kezdetekor a következő elôzetes feltevéseink voltak:

- jobb feltételekkel rendelkeznek a szociális és gyámhivatalok, mint a települési önkormányzatok hivatalai,

\footnotetext{
${ }^{1}$ A kutatást végezte és a kutatási jelentést készítette: Dr. Krizsai Anita és Dr Himics Péter a Foglalkoztatási és Szociális Hivatal megbízásából.
} 
- eltérés lesz a kérdőívvel érintett területen a dolgozók leterheltsége, illetve munkaterhelés tekintetében a szociális és gyámhivatal, valamint a városi jegyzók között,

- a gyakorlatban dolgozók vélhetôen az eljárást szabályozó joganyag egységesítését és egyszerüsítését preferálják, és fontosnak tartanák egységes rendszerek használatát.

A visszaérkezett kérdőívek több mint 3/4-ét kijelölt jegyzôk, míg közel az 1/4-ét szociális és gyámhivatalok töltötték ki. Az általános rész 17 kérdésból állt. Itt kérdeztünk rá a személyi feltételekre, a munkatársak felkészültségére, szakképzettségére, arra, hogy mennyi ideje foglalkoznak az adott területtel, illetve rákérdeztünk a rendelkezésükre álló tárgyi feltételekre.

\section{Személyi feltételek}

Elsôként azt vizsgáltuk, hogy hány munkatárs foglalkozik a múködési engedélyek kiadásával.

A válaszok alapján a hivatalok többségében egy fő foglalkozik ezzel a területtel, jellemzően kapcsolt munkakörben. A vizsgált mintában 147 fő foglalkozott engedélyezéssel, melyből kizárólag ezzel a területtel 58 fó foglalkozott. Kapcsolt ágazaton kívüli feladatok ellátása mellet végezte feladatát 64 fő, és más kapcsolt ágazaton belüli feladat ellátásával is meg volt bízva 25 fô. A válaszadók közül a kettő, illetve három, esetleg négy munkatárs foglalkoztatása a szociális és gyámhivatalokra jellemzô. A válaszokból az is egyértelmú, hogy szintén a szociális és gyámhivatalok munkatársai azok, akik kizárólag ezzel a területtel foglalkoznak. Az engedélyezés feladataival megbízott önkormányzati ügyintézók több mint 1/4-e ágazaton kívüli feladatok elvégzésével is meg van bízva (pl. adóügyek, kereskedelmi múködési engedélyek kiadása). Az ágazaton belül kapcsolt munkakörben dolgozók jellemzóen gyermekjóléti és egészségügyi feladatokat látnak el, illetve segélyezési feladataik vannak. (1. ábra)

A következő kérdésben, ugyanazon bontás szerint, az ellenőrzést végző kollégák számára kérdeztünk rá. Az elsó kérdésre adott válaszokkal azonos megoszlások születtek. A válaszoló szervezetekben 164 fő foglalkozott ellenőrzéssel a vizsgálat idején. Kizárólag ezzel a feladattal 70 fố volt megbízva, 67 fó kapcsolt ágazaton belüli feladatokat is ellátott, míg kapcsolt ágazaton kívüli feladata 27 fônek volt. (2. ábra)

A válaszadók szerint (Szociális és Gyámhivatalok és jegyzői hatáskört gyakorlók $\mathrm{N}=84$ ) csaknem minden esetben azonos volt az engedélyezési és az ellenôrzési feladatokat ellátó személy a hivatalokban.

A Foglalkoztatási és Szociális Hivatal által múködtetett szociális, gyermekjóléti és gyermekvédelmi szolgáltatók, intézmények országos nyilvántartásában 2008. május 31-gyel bezárólag mintegy 3600 fenntartó, 6140 engedélyes került rögzítésre, 


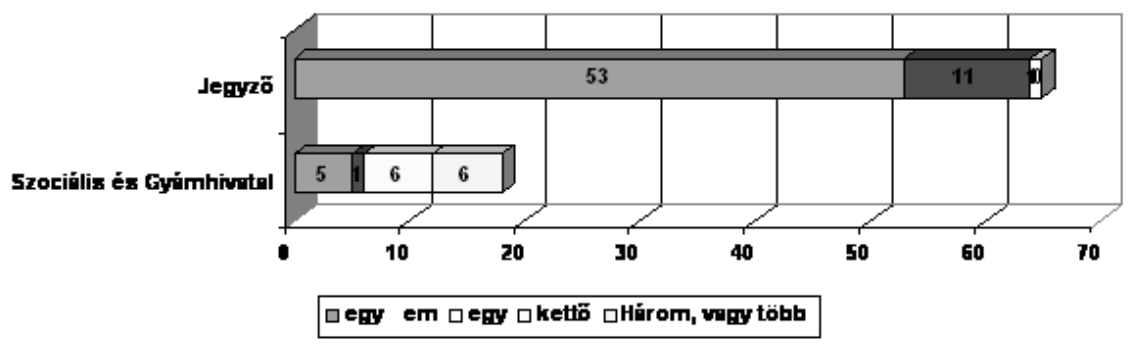

1. ábra. Hány munkatárs foglalkozik kizárólag engedélyek kiadásával? ( $\mathrm{N}=84$; fő)

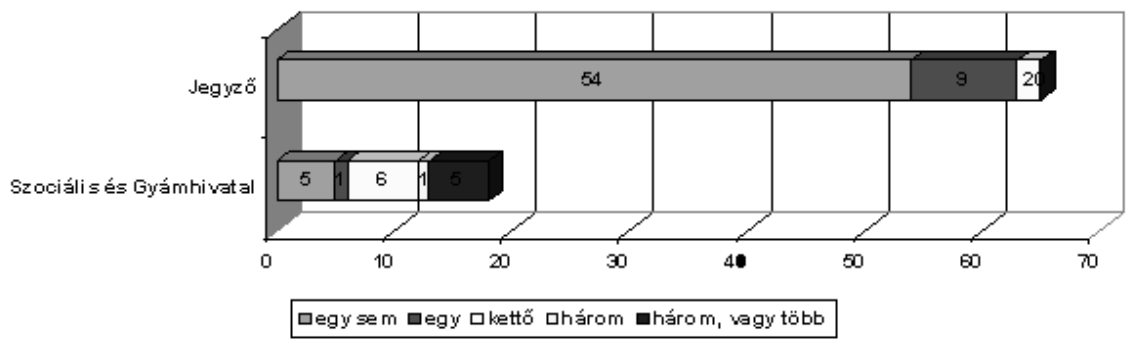

2. ábra. Hány munkatárs foglalkozik kizárólag ellenôrzési feladatok ellátásával? $(\mathrm{N}=84 ;$ fó $)$

az engedélyezett szolgáltatások száma összesen 36.400, közülük 9.900 a gyermekjóléti, illetve gyermekvédelmi szolgáltatások száma. Az engedélyeket 19 szociális és gyámhivatal és 281 kijelölt városi jegyzô adta ki. A kérdésekre adott válaszok és a regiszter adatai alapján megállapítható, hogy a szociális intézmények és szolgáltatások engedélyezésével foglalkozó kollegák leterheltsége az átlagot meghaladó mértékú. Ehhez a városi jegyzók esetében hozzájárulnak az ágazati és sok esetben az ágazaton kívüli feladatok ellátásai is. A kérdôív késôbbi kérdései között válaszként gyakran szerepelt az ügyintézók leterheltségére történő hivatkozás.

Az elôzô kérdésekkel összefüggésben vizsgáltuk, hogy azonos-e a regiszter vezetésével megbízott kolléga az engedélyezés, illetve az ellenőrzést végző kollégával. (3. ábra)

A válaszok alapján szinte minden hivatalban az engedélyezést, az ellenôrzést és a regiszter vezetését ugyanaz a személy/ek végzi/k. A városi jegyzőktől arra a kérdésre is választ vártunk, hogy a múködési engedélyek kiadásával foglalkozó ügyintézô fenntartói feladatokat is ellát-e. A szociális igazgatásról és szociális el- 


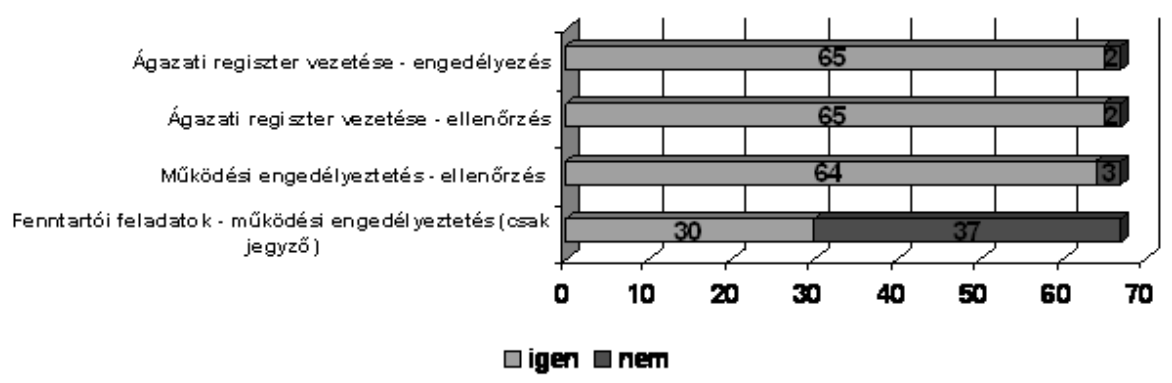

3. ábra. Engedélyezést és ellenőrzést végző kollégák által ellátott egyes munkakörök kapcsolódása. $(\mathrm{N}=67)$

látásokról szóló 1993. évi III. törvény 86. §-a meghatározza a települési önkormányzatok kötelezó feladatait, a 92/B. §-a a fenntartói feladatokat. A válaszok alapján a múködési engedélyezési eljárással, ellenőrzéssel foglalkozó munkatársak közel felének a munkakörébe a fenntartói feladatok ellátása is beletartozik.

A feladatok gyors, hatékony és szakszerü ellátásához szükséges egyrészt a megfelelő szakképzettség, másrészt a megszerzett tapasztalat, ezért az iskolai végzettségre és arra kérdeztünk rá, hogy egy-egy munkatárs hány éve dolgozik ezen a területen. (4. ábra)
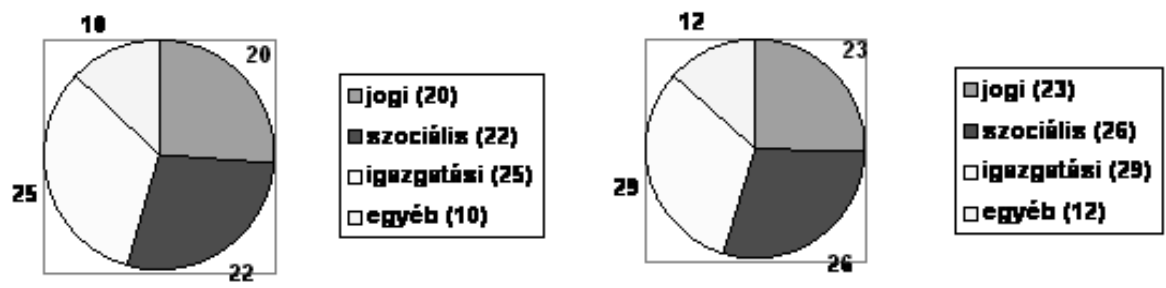

4. ábra. Milyen szakképzettséggel végzik feladataikat a munkatársak a szociális és gyámhivatalokban (balra) és a jegyzôi hatáskörben (jobbra)?(N=83; elemszám)

Megjegyzés: A 4. ábra a szakképzettségek megoszlását mutatja. Feltételezve, hogy egyes munkatársak több szakirányú végzettséggel láthatják el feladataikat, az ábrából nem lehet következtetni a területen dolgozók számára.

A többfajta, jellemzôen jogi, igazgatási és szociális végzettség vélhetôen nagyobb rálátást biztosít a szakemberek számára az ágazati feladatok ellátásában. A 
két ábra alapján jól látható, hogy szinte azonos arányban foglalkoztatnak szakvégzettséggel rendelkezóket a szociális és gyámhivatalok, és a városi jegyzôk.

Ugyanakkor a hivatalok 12\%-ában foglalkoztatnak megfelelő végzettséggel nem rendelkezô munkatársat is. Itt visszautalok az általános részben megfogalmazottakra, mely szerint a felmérés nem volt reprezentatív, hiszen a 100 legtöbb engedélyt kiadó hivatalt kérdeztük meg. Feltételezhetó tehát, hogy a reprezentatív minta alapján ez az érték magasabb lenne.

Az 5. számú ábrán látható, hogy a területeken nem jellemző a kimagasló munkaerô - vándorlás. A dolgozók jelentős része vagy több mint öt éve dolgozik a munkakörében, vagy egy - három éve látja el munkakörét. Ugyanakkor nagyobb számban alkalmaznak új munkatársakat a városi jegyzók.

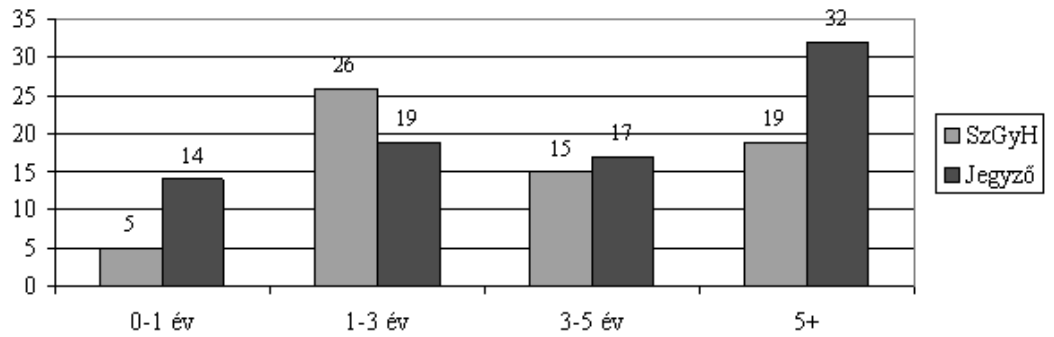

5. ábra. Mennyi ideje dolgoznak ebben a munkakörben?(fő)

\section{Tárgyi feltételek}

Az ágazati és a feladatellátáshoz kapcsolódó jogszabályok folyamatos változása (a személyes gondoskodást nyújtó szociális intézmény és a falugondnoki szolgálat múködésének engedélyezésérôl, továbbá a szociális vállalkozás engedélyezésérôl szóló 188/1999. (XII. 16.) Korm. rendeletet 10 év alatt 33 alkalommal módosították) miatt elengedhetetlen, hogy a területen dolgozó munkatársak munkáját segítsék a központi hivatalok szakmai anyagok kiadásával, szakmai fórumokkal.

Vizsgáltuk, hogy milyen segítséget kaptak a kollegák a feladatuk megfelelő szintű elvégzéséhez. A válaszok alapján szakmai segítséget leginkább a Foglalkoztatási és Szociális Hivatal által kiadott anyagok (92\%), a szakmai továbbképzések (69\%), a Szociális és Munkaügyi Minisztérium által kiadott szakmai anyagok jelentették (65\%). A válaszadók kevesebb mint fele használ a Szociálpolitikai és Munkaügyi Intézet által készített szakmai anyagokat (39\%). A tárgyi feltételeknél elsóként azt vizsgáltuk, hogy az elektronikus ügyintézéshez szükséges feltételek biztosítottak-e, illetve a munkatársak rendelkeznek-e számítógépes ismeretekkel. 
A válaszok alapján rendelkezésre áll a hivatalokban és az ügyintézók megfelelő ismeretekkel rendelkeznek a Word, Excel, Internet, regiszter, elektronikus levelezés, jogtár használatához, azonban a megkérdezett hivatalok felében (51\%) nem biztosított az ügyfélkapu, illetve annak használatát a válaszadók 52\%-a nem ismeri. (6. ábra)

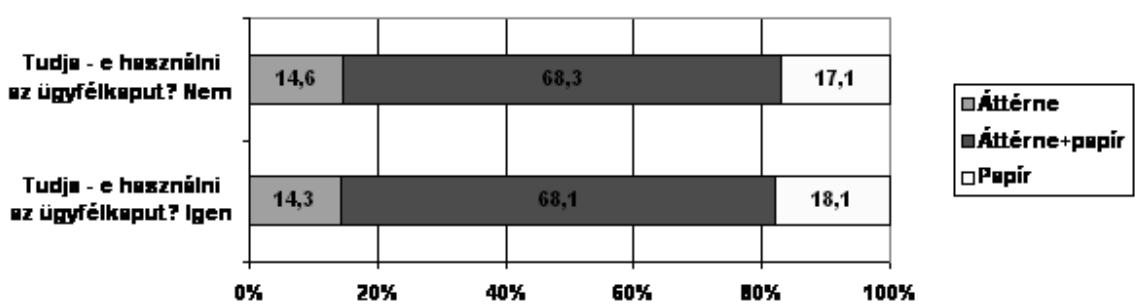

6. ábra. Számítógépes ismeretek megléte, és az elektronikus eljárásra való áttérés összefüggései (\%).

A 6. ábrából látszik, hogy a számítógépes ismeretek megléte, vagy hiánya nem befolyásolja az elektronikus eljárásra való áttérés motivációját. Az ábra az ügyfélkapu használatával való összefüggést mutatja, de hasonló eredményekre jutottunk az egyéb ismeretek (pl. Internet, Word, Excel, stb.) használatával kapcsolatosan is egy - egy százalékpont eltérésekkel. A legjellemzóbb válasz az elektronizálás során az elektronikus és papír alapú eljárások párhuzamos alkalmazása, mely az elektronikus eljárások biztonságával kapcsolatos óvatosságra utal. Az eljárások teljes elektronizálását a Foglalkoztatási és Szociális Hivatal munkatársai javasolták az elektronikus rendszerre való teljes áttéréssel.

A hatóságok véleményét is megkérdeztük az ellenôrzés elektronizálásáról. (7. ábra)

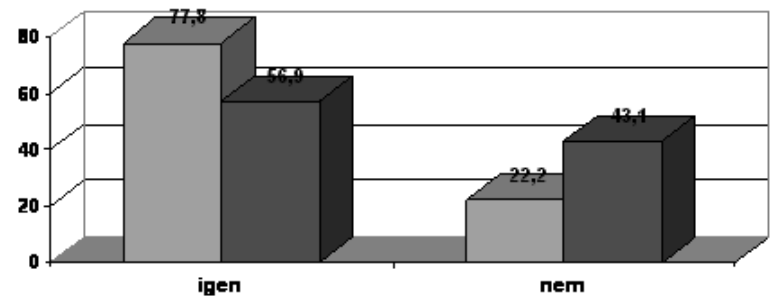

口5zGyH

口Јegyzö

7. ábra. Ellenôrzés elektronizálásának szándéka a hatóság típusa szerint (\%). 
Ha a kérdésre adott választ megvizsgáljuk, akkor nem meglepó, hogy az elektronikus ügyintézéshez szükséges feltételek közel 90\%-át megteremtő szociális és gyámhivatalok inkább preferálják az ellenôrzés elektronizálását.

A továbbiakban arra kérdeztünk rá, hogy az általuk, elsôsorban az ellenôrzéshez, szükségesnek vélt technikai eszközök rendelkezésre állnak-e. A válaszok alapján a leginkább biztosított eszköz a számítógép (92\%), az adathordozó (46\%) és a hivatali gépjármú (54\%). (8. és 9. ábrák)

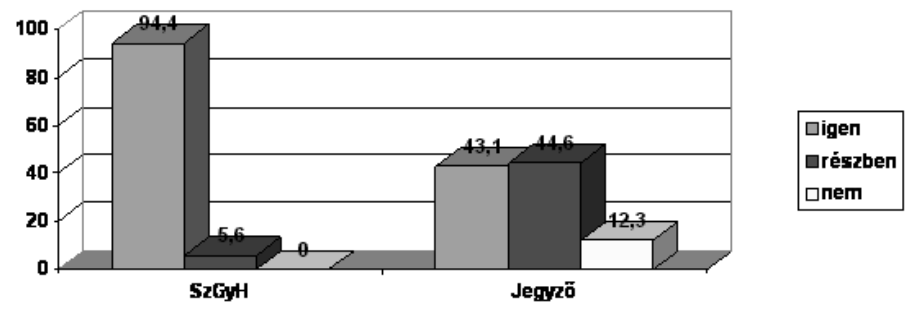

8. ábra. Gépkocsi használata az eljárások során.(\%)
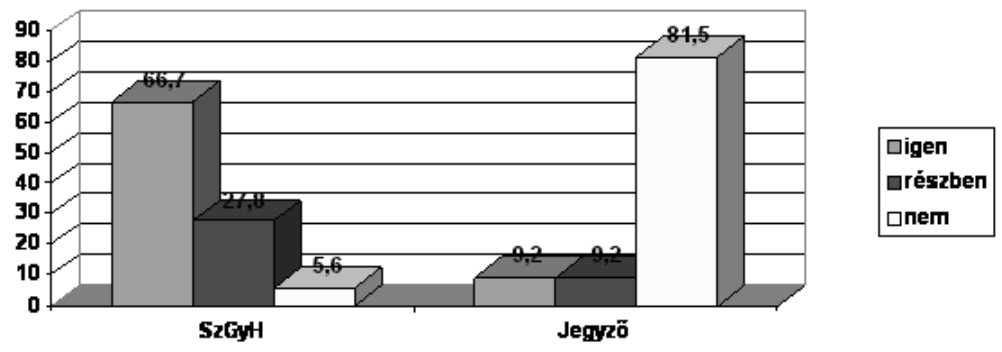

9. ábra. Hordozható számítástechnikai (laptop) eszközök használhatósága az eljárás során. (\%)

Az ábrákból és a feldolgozott adatokból jól látható, hogy az előzetes feltételezésnek megfelelôen a szociális és gyámhivatalok tárgyi eszközökkel való ellátottsága nemcsak a gépkocsi és laptop esetében jobb, hanem a feladat ellátást segítô egyéb eszközök (mobiltelefon, fényképezôgép, személyi számítógép, diktafon, hordozható nyomtató) is jóval nagyobb számban biztosítottak.

Előzetesen azt feltételeztük, hogy a hivatalok múködési engedélyezési eljárása során az 1. elektronikus szint valósul meg, vagyis honlapjukon keresztül tájékoztatást nyújtanak az ügyfeleknek a hivatalukról, az elérhetőségükrôl, az ügymenetrôl, 
a vonatkozó jogszabályokról, szükséges dokumentumokról.

A kérdôívben erre a gyakorlatra is rákérdeztünk. A válaszok alapján a hivatalok 91\%-a ad tájékoztatást a szervezetéról és elérhetôségéról, azonban már csak 59\% közli az eljáró ügyintézó elérhetőségét. A hatóságok kevesebb, mint fele ad tájékoztatást az ügymenetról (45\%), a jogszabályi háttérrôl (40\%) és még kevesebb a csatolandó dokumentumokról (33\%). Mindösszesen a válaszadók 13\%-a tesz közzé általa szerkesztett adatlapot. (10. ábra)
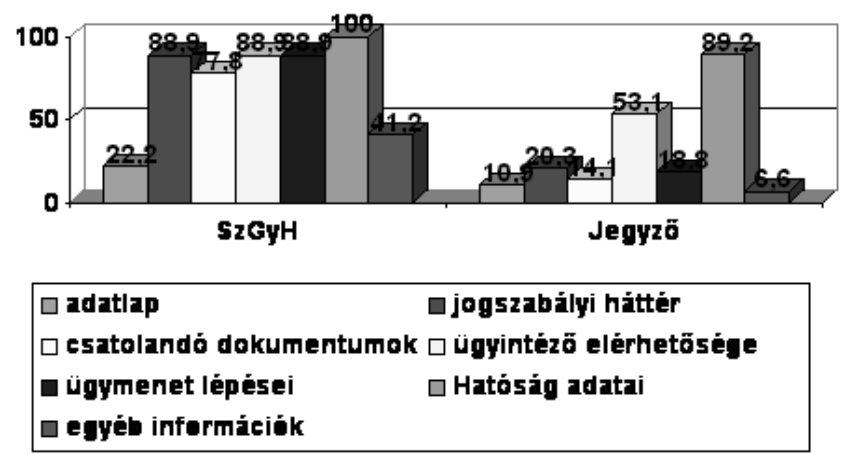

10. ábra. Elektronikusan közzétett információk az eljáró hatóságok között.

A válaszok alapján téves volt az a feltételezés, hogy a hivatalok az elsô elektronikus szint követelményeit megvalósítják. Jelentôs különbség van a két engedélyezố hatóság között. A szociális és gyámhivatalok közel 90\%-ban közzé teszik az adatokat (ez alól az adatlap kivétel). Közel azonos arány csak a hatósági adatok publikációjánál található. A feltételezés jogszabályi kötelezettségen alapult. 2009. október 1-jén lépett hatályba a 2008. évi CXI. törvény, mely többek között a Ket. elektronikus ügyintézéssel kapcsolatos szabályait módosította. A törvény 28/B. § (2) bekezdése szerint, ha törvény, eredeti jogalkotói hatáskörben kiadott kormányrendelet vagy önkormányzati hatósági ügyben önkormányzati rendelet eltérôen nem rendelkezik, az eljárás megindítására irányuló kérelmet benyújtó ügyfél jogosult elektronikus úton kapcsolatot tartani a hatósággal, kivéve, ha az adott kapcsolattartás tekintetében nem értelmezhető. A módosítás a hatóság és az ügyfél közötti elektronikus kommunikáció megvalósulását kívánja létrehozni. Ehhez a hatóságoknak biztosítaniuk kell, hogy szolgáltatásaikat az ügyfélkapun keresztül, vagy elektronikus aláírás felhasználása útján el lehessen érni. Emellett a honlapjukra feltöltött elektronikus tájékoztatáson kívül a tőlük elvárható legszélesebb körû segítséget meg kell adniuk ügyfeleik részére az ügyek minél hatékonyabban történố elintézése érdekében (közzé kell tenni az ügyintézố nevét, hivatali elérhetôségét, ügyfélszolgálat elérhetőségét, ügyintézés határidejét, stb.). A Ket. 164. § (1) bekezdése szerint a hatóság és a 38/A. § szerinti közremúködő hatóság az elektronikus információszabadságról szóló törvényben meghatározott közérdekú adatokat 
- a (2) és (3) bekezdésben foglaltakkal - az ott meghatározottak szerint teszi közzé elektronikusan.

Felmértük a hatóságok elektronikus eljárás bevezetésével kapcsolatos véleményét is. Arra a kérdésre, hogy áttérne az elektronikus ügyintézésre, vagy a papíralapú ügyintézést preferálná, vagy mindkettoót alkalmazná, csak a 72 válaszadó 14\%-a állította, hogy jobb, hozzáférhetóbb az elektronikus ügyintézés, ezért áttérne arra és azt alkalmazná. Azok a válaszadók, akik lehetőséget adnának a papíralapú ügyintézésre továbbra is, vagy csak azt használnák (80\%). Válaszukat azzal indokolták, hogy részben a fenntartók, részben maguk a hatóságok sincsenek felkészülve az elektronikus kapcsolattartásra. (11. és 12. ábra)

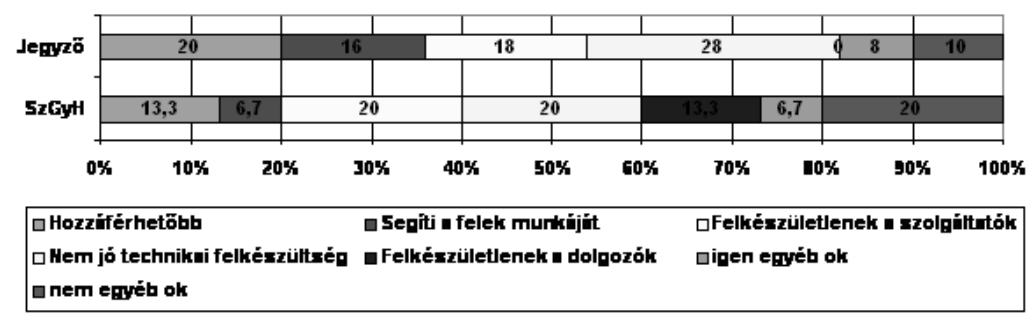

11. ábra. Elektronikus eljárással kapcsolatos vélekedések hatóságok típusai szerint $(\%)$

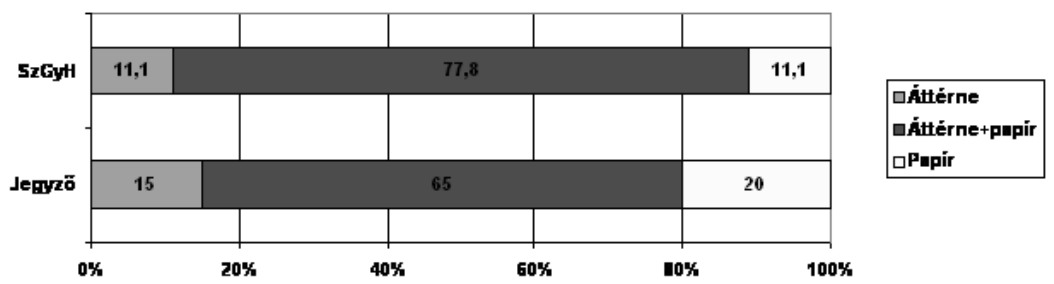

12. ábra. Elektronikus eljárással kapcsolatos vélekedések az eljáró hatóságok szerint $(\%)$

\section{A hatóságok által feltárt problémák}

Feltettük azt a kérdést is, hogy milyen problémákkal találkoznak az engedélyezó hatóságok. A válaszok alapján valószínúleg jelenleg is több olyan intézmény/szol- 
gáltató múködik, akik nem felelnek meg az összes jogszabályi feltételnek. (13. ábra)
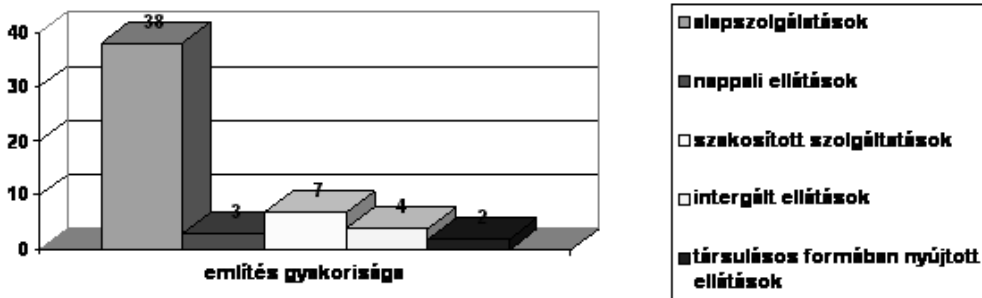

13. ábra. Mely szolgáltatástípusoknál találkozott a legtöbb problémával? (esetszám)

Az alapszolgáltatások múködése során tapasztalat problémák több okra is viszszavezethetók. Legkézenfekvőbb ok nyilvánvalóan a vizsgált szolgáltatások nagyobb száma, de ok lehet az új szolgáltatások megjelenése, illetve ezek nem megfelelô feltételrendszere is, finanszírozási nehézségek, illetve a jogszabályok folyamatos változása. (14. ábra)
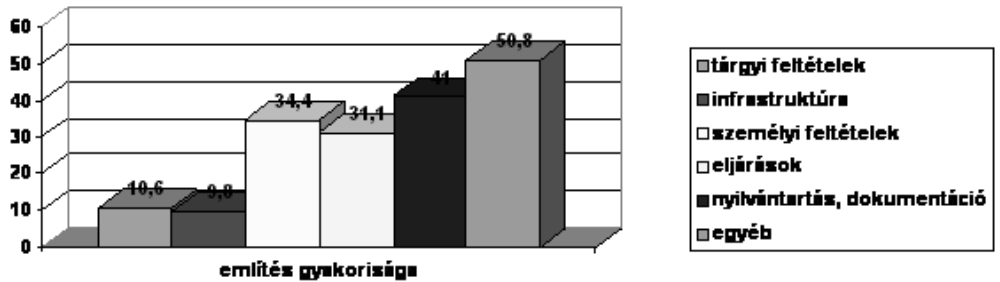

14. ábra. Milyen problémákkal találkozott az ellenőrzések során? (említés gyakorisága szerint \%)

A 14. ábrából jól látható, hogy nem szúkíthetô le néhány problémára a kérdés. A válaszadók fele egyéb okokat nevezett meg a személyi feltételek, a nyilvántartás, dokumentáció hiányosságai mellett. Az egyéb okok között szerepel például a térítési díjak nem megfeleló megállapítása. Szintén az egyéb kategória tartalmazza azokat a válaszokat, mely szerint a fenntartók nem rendelkeznek kelló jogszabályi ismerettel, ezért nem teljesítik megfelelően a követelményeket.

Megoszlanak a válaszok abban a kérdésben, hogy a hiányosságok felszámolását hogyan ellenőrzik a hatóságok. Következó soros ellenőrzés alkalmával (43\%), 
utóellenőrzéssel a helyszínen (39\%), dokumentumok bekérésével (48\%), fenntartói nyilatkozat alapján (52\%). A válaszok eloszlása közel azonos, mely visszavezethetô arra, hogy a jogszabályokban nem található erre nézve szabályozás. Az ellenôrzés során leginkább az intézményvezetôtôl és a fenntartótól kérnek tájékoztatást.

Az ellenôrzést jellemzóen egy (55\%), de legfeljebb két fô végzi (23\%).

A válaszadók több mint fele nyilatkozott úgy, hogy nincs elég idó az alapos vizsgálat elvégzésére (52\%). Indokként az osztott munkakört jelölték meg. Az ellenôrzés időtartamát tekintve jellemzóen egy nap (74\%) szükséges a helyszíni ellenőrzéshez.

A válaszadók közel negyede a teljes vizsgálat lefolytatására 5 napnál többet fordít. Ha összevetjük a választ azzal a válasszal, hogy az ellenórzéseket jellemzốen a helyszínen végzik vélhetôen a jegyzőkönyvek készítése vesz jelentősebb időt igénybe.

A válaszadók többsége (79\%) használ szempontsort, ebból $54 \%$ használja az FSZH által készített útmutatót.

Likert skálával vizsgáltuk azt, hogy az ellenôrzô hatóságok tapasztalatai alapján a fenntartók által nyújtott szolgáltatások színvonala emelkedett vagy sem. (15. ábra)

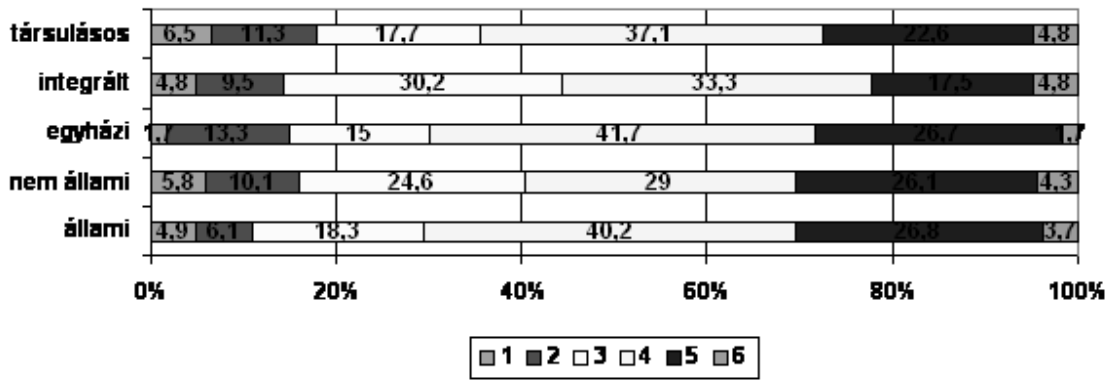

15. ábra. Az ellenôrzést követôen a szolgáltatások színvonala emelkedett (\%) (Ahol az egy az egyáltalán nem ért egyet, a hat a teljesen egyetért értéket jelenti)

A válaszok alapján a színvonal minden típusú fenntartónál emelkedett, de inkább kisebb mértékben.

Megvizsgáltuk, hogy a munkatársak szükségesnek tartanák-e egységes képzés kidolgozását az ellenőrzések hatékonysága érdekében. A válaszadók 93\%-a vélekedik úgy, hogy segítené munkájukat. Ezzel összefüggésben arra is rákérdeztünk, hogy elégségesnek tartják-e az ellenôrzés szabályanyagát. A válaszadók 70\%-a nem tartja annak.

Arra a kérdésre, hogy szükséges-e egységes eljárási gyakorlat, megoszlanak a vélemények, már csak a válaszadók 54\%-a tartja szükségesnek. 
A válaszok alapján nem rajzolódik ki egységes álláspont abban a tekintetben, hogy esetlegesen egy központi hatóság irányítása alatt egységes ellenőrzési gyakorlat bevezetését szükségesnek tartanák, vagy inkább szeretnék a hatóságok saját szempontjaik szerint az ellenőrzési feladataikat elvégezni.

\section{VI. Összegzés}

A felmérés eredményei a következók voltak:

- Az önkormányzatnál dolgozó munkatársak az engedélyezéssel és ellenôrzéssel kapcsolatos feladataikat többségében kapcsolt munkakörben végzik. A munkájukhoz szükséges tárgyi feltételek kevésbé biztosítottak, mint a szociális és gyámhivatalok esetében. Mivel jellemzően egy fő végzi a feladatot, esetükben fontos szerepe lenne a képzéseknek és a közigazgatási hivataloktól kapott segítségnek. Egyik hatóság esetében sem jellemzô a munkaerô-vándorlás, és mindkettônél hasonló arányban foglalkoztatnak szakképzett munkaerôt.

- Az elektronikus ügyintézés terén a szociális és gyámhivatalok inkább megvalósították a jogszabályi követelményeket, mint a városi jegyzók, és ezzel összefüggésben jobban preferálják az egyes eljárások elektronikussá tételét. Ugyanakkor mindkét hatósági típus bizonytalan az elektronikus eljárással kapcsolatosan.

- Az engedélyezési eljárás szabályozásával kapcsolatban általános elvárásnak és kívánalomnak tekinthetô az eljáró hatóságok azon igénye, hogy a jogszabályi módosításokat követően egységesebb, gyorsabb, kiszámíthatóbb legyen az eljárás, megfelelve ezzel - a fenntartók, szolgáltatók, illetőleg a szolgáltatást igénybe vevô ellátottak szempontjából is rendkívül fontos - jogbiztonság elvének.

- Egységes a vélekedés, hogy az engedélyezési eljárás egyszerúsítését, gyorsítását az elektronizálás magasabb szintje (is) jelentheti, amelynek feltétele azonban egyrészt a tárgyi és személyi feltételrendszer javítása, másrészt a jogszabályi környezet megfelelő módosítása. A felmérésben megkérdezettek tekintélyes részének véleménye szerint az elektronikus eljárás bevezetésének technikai feltételei, sem az engedélyezô hatóságok, sem pedig a fenntartók esetében nem állnak fenn, továbbá jelentôs százalékuk véli úgy, hogy a feltételek csak részben biztosítottak.

- Az elektronikus eljárásra való áttérés alapjai, a résztvevő fogadókészsége a jelenlegi rendszerben és gyakorlatban is megvannak, azonban a teljes áttéréshez tekintélyes fejlesztésekre lenne szükség. Ennek legfontosabb előfeltételének az eljárások egységesítése, az átláthatóbb, stabilabb jogi szabályozás tekinthetô. 
- Az ellenôrzések alapján a hatóságok továbbra is tapasztalnak hiányosságokat jellemzôen az alapszolgáltatások esetében. A jogszabályok nem kellô ismerete miatt fôleg az eljárások és a dokumentációs rend, a nem megfelelő adminisztrációt nevezik meg hibaként. A személyi feltételek nem megfelelő biztosítása is probléma. A hiányosságok oka lehet a vizsgált szolgáltatások nagyobb száma, de ok lehet az új szolgáltatások megjelenése, illetve ezek nem megfelelô feltételrendszere, finanszírozási nehézségek, illetve a jogszabályok folyamatos változása is.

- A hatóságok nagyobb jogbiztonságot várnának, a munkájuk segítéseként fontosnak tartják a szakmai anyagok megjelentetését (jelenleg a gyakorlatban fóleg az FSZH anyagait használják), illetve fórumok, képzések tartását, de a válaszok alapján nem olyan egyértelmú, hogy szeretnék ha a munkájukat direkt módon irányítanák.

A Foglalkoztatási és Szociális Hivatal 2010. évi adatai szerint 281 kijelölt városi jegyzố végez szociális és/vagy gyermekjóléti ellenôrzési feladatokat, a kiadott múködési engedélyek száma összesen 7080 db (2008. évben 6140 db). A társadalmi és jogszabályi változások következtében szinte folyamatos ezen engedélyeknek a módosítása, felülvizsgálata, illetve az engedélyek alapján a múködés ellenôrzése.

A felmérés eredményei alapján valóban indokoltnak túnik a feladatok centralizációja, hiszen a kormányhivatalok részeként múködô szociális és gyámhivatalok jobb személyi és tárgyi feltételekkel rendelkeznek, valószínúleg hatékonyabb lesz a feladatellátás, mivel jellemzóen nem osztott munkakörökben végzik feladataikat, és a joggyakorlat is egységesebbé válik, hiszen a hatóságok száma jelentősen csökken.

Véleményem szerint azonban a hatáskör elvonásnak lesznek negatív következményei is:

- A szociális és gyámhivatalokban jelentôs mértékú létszámfejlesztés szükséges, együttesen a tárgyi feltételek biztosításával. Jelenleg több mint 400 fô végzi azt a tevékenységet, amelyet a 19 szociális és gyámhivatal végez 2011. július 1-től.

- A szociális és gyámhivatalok jelenleg is leterheltek, az engedélyezési eljárás sok esetben elhúzódik, az ellenôrzési feladatok sem teljesülnek teljes mértékben. Egyéb feladataik ellátása pl.: tájékoztatók tartása, felkészítés jogszabályi változásokra, stb. sem teljesül maradéktalanul.

- Az önkormányzat (illetékes városi jegyzô szerinti településen) az engedélyezések következtében napi kapcsolatban áll a területükön szolgáltatást nyújtókkal, intézményt fenntartókkal (nem állami és egyházi fenntartók együttesen). Az ellenőrzések kapcsán személyes tapasztalatok, ismeretek, benyomások alakulnak ki és állnak rendelkezésre. Ez segíti az önkormányzat munkáját a személyes gondoskodást nyújtó ellátások, illetve az ehhez kapcsolódó egyéb feladatok (pl. szociális kerekasztal) szervezésében. A jogszabály változtatás 
hatására az önkormányzat területén múködő szolgáltatók megismerése nehezebb lesz.

- A kijelölt városi jegyzók tapasztalatukkal, ismereteikkel számos esetben segítik a település és a kistérség településeinek munkatársait.

Az elmúlt 17 évben folyamatosan növekedtek az önkormányzatok szociális és gyermekjóléti/gyermekvédelmi szolgáltatási és hatósági igazgatási feladatai. Jelentôs részük megfelelô anyagi erôforrás hiányában nem volt képes, és ma sem tudja teljes mértékben ellátni azokat. A jelenlegi kormányzati törekvések alapján az önkormányzatokkal szemben az állam szabályozó és ellenôrzô funkciójának a megerôsítése történik a végrehajtott centralizációs lépések által. Ez látszólag kedvezően érinti az önkormányzatokat, hiszen csökkenek a feladataik. Számomra azonban fontos kérdés, hogy az önkormányzatoknak a jövôben milyen szerepet szánnak a helyi jóléti ellátások biztosításában. Az önkormányzatiság a jövooben is garancia kell legyen ahhoz, hogy az állampolgárok hozzájussanak a megfelelő minőségú szolgáltatásokhoz, ehhez azonban az szükséges, hogy az önkormányzatoknak legalább a szükségleteket felmérô, koordináló, szervezô szerepe megmaradjon.

\section{Hivatkozott jogszabályok}

1. A szociális igazgatásról és szociális ellátásokról szóló 1993. évi III. törvény.

2. A közigazgatási hatósági eljárás és szolgáltatás általános szabályairól szóló 2004. évi CXL. törvény.

3. A személyes gondoskodást nyújtó szociális intézmény és a falugondnoki szolgálat múködésének engedélyezésérôl, továbbá a szociális vállalkozás engedélyezéséről szóló 188/1999. (XII. 16.) Korm. rendeletet.

4. A szociális szolgáltatók és intézmények múködésének engedélyezéséról és ellenôrzésérôl szóló 321/2009. (XII. 29.) Korm. rendelet.

5. A gyámhatóság szervezetérôl és illetékességérôl szóló 331/2006. (XII. 23.) Korm. rendelet.

Krizsai Anita: Nyíregyháza Megyei Jogú Város Polgármesteri Hivatal, Szociális Osztály 